\title{
Exploration on ideological and political teaching modes at colleges under micro-era utterance
}

\author{
Yuxia Wang \\ Shangdong Woman's University, Ji'nan 250022, China
}

Keywords: Micro-era utterance; Colleges; Ideology and politics; Teaching modes; Inquiry

\begin{abstract}
With continuous development and progress in science, network application has been popularized and micro era has arrived. To improve teaching quality of ideological and political courses, contemporary colleges should carry out reform of teaching modes. This thesis discuses exploration on ideological and political teaching modes under micro-era utterance in the following aspects, including microblog and subject inquiry mode under micro-era utterance, advantages brought by using microblog to develop ideological and political subject inquiry teaching modes, framework design and implementation of ideological and political teaching modes at colleges under micro-era utterance and problems we should pay attention to when we use microblog platform to develop subject inquiry. Ideological and political courses in college education aim at improving students' ideological and political quality and providing a correct direction for students to establish their outlook on life, value and even world outlook. We need explore a teaching mode that is more appropriate for features of contemporary college students and improve teaching effectiveness of ideological and political courses in Chinese colleges further when we enhance students' knowledge level.
\end{abstract}

\section{Basic concepts and advantages}

(I) Microblog under micro-era utterance

Microblog is a platform where users share and spread information and a micro blog. It has functions like attention, live telecast, remark and forwarding and acts as a network platform at which users can express their thoughts and communicate with others most conveniently and most rapidly. In China, Sina opened Sina microblog in August 2009. The number of its registered users reached 30 million within one year. By the end of December 2013, the number of people using microblog in China had rose to over 0.5 billion, which increased by 0.2 billion compared with that in the corresponding period of 2012.

Microblog has experienced long-term development so far, people using it in our country expand continuously. To consolidate position of microblog in netizens, Sina microblog carries out continuous innovation and development in order to satisfy netizens' opinions and demands, enable them to use the microblog platform in different aspects and to different degrees and keep its growth rate constantly.

(II) Subject inquiry teaching mode

It is Dewey a famous educator in America that put forward subject inquiry teaching mode for the first time. Later, the mode was applied by Professor Schwab to teaching, who elaborated connotation and advantages of the educational mode soon afterwards. In recent years, the Schwab has drawn wide attention from educational world in the whole world and each country has tried to explain this subject inquiry teaching mode. In case of success, they will introduce it to their own theory of educational courses.

The subject inquiry teaching mode is an inquiry-based learning mode which treats students as subjects and combines topicality with inquiry. It is also a teaching mode guiding students to study subjects of teaching on the basis that teachers have integrated teaching materials to drive students to comprehend knowledge. This teaching mode can enhance students' dominant position in teaching, cultivate students' ability in many aspects, such as autonomous learning ability and cooperative and communicative competence and has positive acceleration on students' comprehensive development. 
Some experts and scholars in the society also develop specific teaching practice about the teaching mode and obtain good achievements nowadays. Thus, exploration on microblog-based ideological and political teaching modes of colleges under micro-era utterance means teachers publish classroom-related tasks in microblog and students will learn and master such tasks, develop inquiry learning and show teaching achievements in classroom after reading them.

(III) Advantages brought by using microblog to develop ideological and political subject inquiry teaching modes

Although length of a piece of writing published by microblog is short each time, it provides a stage where people can express their opinions, make friends and show themselves. According to an investigation on Chinese college students' use about microblog, it is found that the number of students who have registered microblog has accounted for $90 \%$ of the total number of college students and coverage of microblog is wide; college students browsing microblog more than once a day account for $90 \%$ of such students and $80 \%$ of them spend 20 minutes on microblog at least, which indicates the frequency at which college students use microblog is quite high; college students log in microblog by computer and mobile phones basically and $95 \%$ of college students use mobile phones to log; behaviors after logging in microblog are various and students browsing microblog by mobile phones in classroom can be found everywhere. It is obvious that college students love microblog such a platform very much. Thus, political courses of schools may utilize this to combine microblog with education, change teaching modes of ideological and political courses at colleges and then improve teaching quality of ideological and political courses. Advantages brought by using microblog to develop ideological and political subject inquiry teaching mode mainly contain the following aspects.

1. Low admittance criterion and plebification

Users may log in microblog as long as they make registration and there is no complicated step. All college students regard this as a standard for fashion and use it frequently in life. Ideological and political teachers of colleges may register dedicated microblog, require students to pay attention to and publish civilian information related to ideological and political education theory. In doing so, students can read information when they browse microblog every day.

2. Diversified ways to publish information on microblog and instantaneity of information spreading

Internet technology develops continuously and ways to publish information on microblog also increase. Users may publish information on microblog in many ways and by instant communication tools like short message service, multimedia message and WAP browser. These diversified ways provide convenience for teachers to and students to publish teaching subjects and receive inquiry task on internet, respectively, and enable teaching activities about ideological and political courses in colleges to be developed at any time.

3. Strong interaction of microblog

Microblog has several functions, such as attention, forwarding and comment. Students can read the content published by their teachers by different methods, which overcomes time-space limitations of traditional interactive methods to some extent. Teachers may publish some content that is closely related to content of teaching materials. After reading, students may give comments or forward it and express their doubts and questions. Seeing this, teachers may answer students' questions with pertinence in time.

4. High speed of information dissemination

Microblog dissemination is very fast like virus. Take Ya'an Earthquake for example. The piece of information about earthquake was published on Sina microblog and the quantity of forwarding within several seconds exceeded people's imagination largely. Thus, people knew this event in a short time. It was microblog's ability to spread and diffuse information that fought for precious time for rescue. Ideological and political teachers of colleges may utilize the feature of microblog to develop ideological and political education for college students completely. 


\section{Framework design and implementation of ideological and political teaching modes at colleges under micro-era utterance}

(I) Class purpose

The subject inquiry teaching mode just carries out teaching activities in the form of teamwork. Since students become subjects of learning, teamwork appears to be very important. The mode aims at improving students' knowledge, ability and quality comprehensively and making students comprehend the knowledge they have learned better after a series of exploration on students' independent learning and cooperation.

(II) Teaching link

1. Choosing research subjects

We must not choose inquiry subjects randomly but relate them to teaching content closely. Ideological and political courses of colleges should help students establish correct outlook on life, value and view of law system etc and make students get clear cognition. Established subjects should accord with students' physical and mental development level. If inquiry subjects designed by teachers exceed students' ability, they will have difficulty in acceptance and expected effect cannot be realized. Therefore, subjects should be selected with pertinence and approach students' life. Subjects that can arouse students' interests should be selected, which can also enhance students' research motivation. Besides, subjects should be clear rather than be equivocal.

\section{Teaching form}

Generally, ideological and political courses of colleges are given in the form of an enlarged class, which leads to bad teaching effect. It is essential to group students, i.e., 6-10 students form a team and one of them is elected as a team leader to guide students to carry out exploration so that all students can participate. During exploration, all students should propose their opinions and seek common points while reserving difference in groups to sublimate theoretical knowledge. The leader of each group should be responsible for paying attention to dynamic states on microblog and pass inquiry content published by teachers on microblog to other students, which can not only ensure efficiency of ideological and political courses but also promote students to get team spirit.

3. Teaching process

First of all, teachers should publish subjects, content and requirements for tasks that need be explored in teaching by microblog so that groups can discuss them. Finally, achievements of discussion are shown in different forms. In the process of inquiry, group members may consult teachers by comments on microblog in case of any question and teachers ought to answer students' question in time in order that both teachers and students benefit on the basis that teaching goals have been realized.

4. Teaching evaluation

Achievements of inquiry learning may be evaluated in three aspects, i.e., 'teachers, group leaders and students'. Teachers should evaluate students' inquiry process and achievements; group leaders ought to evaluate whether group members have high enthusiasm when they make discussion and other group members should also evaluate learning achievements of other groups. This evaluation mechanism may generalize students' learning performance overall, enhance their attention to ideological and political courses largely and strengthen effectiveness of classroom inquiry.

5. Performance assessment

Ideological and political courses emphasize practice and aim at cultivating students' capability of knowing and doing. Course assessment is divided into theoretical performance and ordinary performance and both of the two occupy $50 \%$ of total performance, respectively. Theoretical performance may be obtained by many assessment methods, such as paper assessment, interview and dictation and paper writing. Ordinary performance is evaluated from an objective perspective and according to evaluation of teachers, group leaders and students.

III. Problems we should pay attention to when we use microblog platform to develop subject inquiry

(I) Currently, the number of microblog users increases continuously and splendid and abundant 
microblog topics emerge in endlessly. Ideological and political teachers of colleges must operate their educational microblog well and make students browse their microblog and show interest in participating in comments and forwarding. This can have teaching effect on ideological and political courses of colleges. Besides, teachers' microblog should have abundant content, give comments on current situations, answer students' questions uniformly or express interesting things and feelings they encounter in daily life etc.

In addition, Ideological and political teachers of colleges may forward others' microblog with profound thoughts, interact with students by elaborate operation, overcome limitations of classroom teaching and then improve effect ideological education on college students. To operate microblog well, teachers may accumulate over a long period, insist on doing this for a long time and spend much time and energy. This requires teachers should have strong professional dedication and spirit of utter devotion.

(II) Ideological and political teachers should communicate and exchange with all group leaders and group members and learn students' learning after class. After communication and exchange, teachers may learn students' thoughts, learning and life sufficiently and provide favorable gurantee for teaching students in accordance with their aptitude in classroom teaching.

(III) The teaching mode under micro-era utterance aims at improving students' independent learning ability, emphasizes students' dominant role and enables students to comprehend and master theoretical knowledge about ideology and politics in the process of learning. However, teachers' leading role in teaching cannot be weakened by this. Teachers should take a lead to design teaching content, organize classroom teaching, monitor students' inquiry process and evaluate students' learning achievements, and guide students to carry out learning activities.

Ideological and political courses of colleges are special, which are completely different from the ones at primary and middle schools. They require students should not only master theoretical knowledge about ideology and politics but also implement independent practice. However, ideological and political classroom needs teachers' teaching and teachers must not hand teaching hours of the whole classroom to students.

\section{Conclusion:}

Using microblog to carry out subject inquiry on ideological and political courses of colleges should be performed under the foregoing modes. Ideological and political teachers of colleges should comprehend points mentioned above carefully, enhance and improve ideological and political teaching modes under micro-era utterance and create new-type ideological and political teaching modes.

\section{Reference}

[1] Yan Jiangbo, Jian Panfeng. Problems in ideological and political education of college students under microblog era and countermeasures [J]. Journal of Yulin College, 2012(04).

[2] Huang Danlin. Microblog-based interactive mode of ideological and political education in colleges [J]. Journal of Anqing Normal University (Social Science Edition), 2011(05).

[3] Zhang Kun. Acceptance, transformation and innovation - New exploration on ideological and political education of college students in the field of pop culture [J]. Journal of Liaoning Institute of Science and Technology, 2007(02).

[4] Wang Zeyu, Yang Ling. Challenges ideological and political education faces with in network era and countermeasures - brand-new thinking from the perspective of communication [J]. Heilongjiang Researches on Higher Education, 2004(07).

[5] Bai Wu. Ideological and political education of college students from the perspective of 'Scientific Outlook on Development' [A]. Memoir of 'Scientific Outlook on Development and Social Development of Guizhou' seminar \& Guizhou Sociology Academy in 2006 [C], 2006. 
[6] Chen Weihong, Chen Wenyuan. Ideological and political education of students in our school and their healthy growth [A]. Collection of excellent papers of Higher Vocational Technical Education Branch of Yunnan Association of Higher Education in 2008 [C], 2008.

[7] Ren Chenwei, Liu Lan, Chen Lijun. Impacts of microblog on vocational college students' ideological and political work and its application [J]. Journal of Yueyang Vocational and Technical College, 2012(02).

[8] Hou Peiyong, Yang Shangqin. Humble opinions on college students' psychological health education [A]. Memoir of the national $7^{\text {th }}$ academic exchange conference about college students' psychological health education and psychological health education of College Students' Psychological Counseling Specialized Committee of China Association for Mental Health \& the $10^{\text {th }}$ anniversary of establishment of the specialized committee [C], 2001.

[9] Peng Yanhong. Innovation of ideological and political education at colleges under microblog era [J]. Journal of Chifeng University(Philosophy and Social Science), 2012(08).

[10] Fan Yunyun, Bi Ying. Covering college students' ideological and political education with a warm 'neckerchief' - on microblog and college students' ideological and political education [J]. Science and Technology Information, 2010(21). 